\title{
Does the Scientific Progress Dispense the Teaching of Biological Evolution?
}

\author{
Heslley Machado Silva ${ }^{1}$, Daiana Evilin Gibram ${ }^{1}$, Graça Simões de Carvalho ${ }^{2}$ \\ ${ }^{1}$ Unifor-MG, Brazil \\ ${ }^{2}$ University of Minho, Portugal
}

\begin{abstract}
Nowadays the teaching of biological evolution faces the creationist movement that claims this theme has no scientific evidence and that it could be excluded from the educational system. A challenging question about whether the exclusion of the teaching of Darwinian Evolution would harm the scientific progress was asked to a Brazilian population sample. In general, the results showed a rejection of the above question. Among the religious respondents, Spiritualists were those showing higher acceptance of the proposed statement whereas the Evangelicals were those less agreeing with the proposed question and with a considerable percentage of disagreement; Catholics were in a median position, agreeing with the question and a few rejecting it. The more educated the respondents were the higher acceptance of the question. The present study revealed that even the inquired creationists recognize that the teaching of biological evolution is essential in modern science.
\end{abstract}

\section{Introduction}

Supported by a large body of evidence, the topic of biological evolution has become a major pillar of modern science. Indeed, it is hard to find a student that has not been in contact with the Darwinian Theory in his/her academic path anywhere in the world [1]. There is a network of evidences leading to concepts that underpin the evolutionary theory, which in turn sustain theoretical models allowing predictions. Such predictions when confronted by new empirical results may or may not generate changes in the theoretical models. Much of Darwin's contribution to science was just to be able to gather a series of observations coming from different fields and synthesize them to explain the common ancestry [2].

The arguments and interpretations contrary to Darwinian evolution and its teaching are related to dogmatic positions, especially in relation to the Old Testament, as understood in its literal sense. Even the most logical and empirical evidence that are perceived and presented in scientific circles seem to have almost no impact on fervent believers [3], but it is worth questioning whether even that religious practitioner recognizes some value in Darwinian theory. It is worth to investigate this dilemma, because functional biology is basically Darwinian. It is also relevant to know whether such dogmatic religious practitioners accept creationist views and/or the pseudoscientific version of Intelligent Design, which advocates the existence of a creator directing the evolution in a scientific and educational way. This functional biology returns to a pre-Darwinian era, and renounce all the postulates established by science, based on the Darwinian Theory [1]. Caldeira et al. [4] report that anti-evolutionists have views of the origin of humanity and the Earth entirely opposed to those of the scientific field, so that these radical creationists refuse definitely the evolutionary theory, hindering any intermediate vision.

In the Brazilian context, this type of research is relevant as, according to Silva and Mortimer [5], the conflict between science and religion can be stressed in the near future since the two major growing groups in the Brazilian religious spectrum have opposing opinions. Indeed, data from the last Brazilian census revealed that no-religious and Evangelicals are the highest growing communities , the latter proving to be very much aligned with dogmatic assumptions, such as the Young Earth Creationism and Intelligent Design.

Berkman and Plutzer [6] claim the importance of the teaching of biological evolution in the curriculum, especially in secondary school, due to its unifying role in biology. These authors also emphasize the role of Darwinian Theory to show. students how modern science works and how it is essential to the understanding and progress of biological areas such as genetics, agriculture and health, among others. These authors discuss the cycle of ignorance that can be established in the case of teachers spending little or no time to this topic so that students do not learn about the Theory of Evolution and are not aware of the fundamental role of biological evolution on the progress of science. This needs to be further investigated. Rutledge and Mitchel [7] question whether the teachers' background and the time required to master the content of biological evolution are related to the acceptance of controversial issues, like evolution, by the population; similarly, whether there is a relationship between the teachers' denial of the controversial issue and the society acceptance. Caldeira et al. [4] have found that the teachers and students of Biological Sciences can recognize the importance of natural selection to the evolutionary process, but do not invalidate the idea that a Creator has guided this process.

In 2009, a series of celebrations for the anniversary of the birth of Charles Darwin and the 
release of the most impactful book "The Origin of Species" took place. Since the publication of this book, the issue of Darwinism and the teaching of evolution was in vogue both in scientific and lay media [8]. On the other hand, there has been a strong reappearance of creationist movements, being initially limited to the United States, but currently echoing around the world, and most notably in Brazil [5]. This rebirth of the creationist view may come from a reaction to the confirmation of the importance of Darwinism, especially in the educational field [6], but may also be related to more fundamentalist religious view, highlighting the biblical text as the only reliable source of knowledge and moral stance [9].

The creationist movement has many facets, more or less radical. One must be careful with generalizations but, in general, these movements are aggregated into a global trend, which refuse definitely the Darwin's ideas about the evolution of species, notably with regard to the human origin [9]. This rejection leads to deficiency of basic knowledge of modern biology, which is takes evolution as its guiding principle. So taking the creationists arguments would refute the current way of doing science, with its network of experiments and results that mutually support themselves [2].

The creationist movement has found field in Brazil, with the growing number of faithful and, especially, evangelical churches, which are mostly rooted in the literal interpretations of the biblical text. This growth is reflected in the political field and also in the educational field, with proposals for teaching creationism outside the scope of religion classes, being seen as an element of balance to the prevalence of biological evolution, even in science classes [2].

Numbers [10] indicates that among all Latin American countries, Brazil has a more active antievolutionist movement, deeply rooted in the society. This entrenched creationist movement is reflected in the recent emergence of two creationist societies, the Brazilian Association of Creation Research and the Brazilian Creationist Society. In education, there are also some examples of the creationist influence, such has the traditional Mackenzie College in São Paulo, which uses the creationist perspective in science classes and the University Center of São Paulo (UNASP), which often conducts meetings with international figures aligned with the creationist thinking that counteract the Evolution view [9]. It is important to highlight the survey results by the Brazilian Institute of Public Opinion (IBOPE) revealing that $33 \%$ of Brazilians believe that man was created 10,000 years ago (mainly believers of the Young Earth Creationism) and 54\% believe that man is the result of an evolution of millions of years which was guided by God (mainly believers of the intelligent design). For these authors, the most critical point of their research is that $89 \%$ of Brazilian respondents think Creationism should be taught in schools and, more worryingly still, $75 \%$ believe that this concept should be addressed instead of Evolutionism.

This reborn intense Creationism has also been claimed by Shapin [11] who says that the biblical fundamentalism contrary to Darwinian biological evolution is stronger nowadays, in the early $21 \mathrm{st}$ century, than in Victorian times. Especially the existence of Young Earth Creationists, among people with some or little education would be greater today than at the time of Darwin. The same author [11] points out that in the Gallup poll of 2008, in the United States, only $14 \%$ of the population believed that human beings are the result of an evolution of millions of years without the participation of a God. Willemart and Marques [12] consider that there is a continuum among those who deny the theory of evolution, being the Young Earth Creationists the most extreme creationists that are present in considerable numbers in Brazil and in the United States. These extremists deny many of the scientific advances, but other creationists with a higher level of education and openness to science would accepting gradually the scientific findings related to various fields, including the Theory of Evolution.

Despite all this generalised creationist view, Gleiser [13] points out that there are religious leaders (priests, rabbis and pastors) who recognize that the idea of the earth has appeared before 10,000 years and that Adam and Eve have emerged to form humanity is absurd. A growing number of religious congregations consider that one should not turn a blind eye of science, being possible to preserve religious values; in addition, it helps to keep the cohesion of religious thinking and an update of its views, reflecting on the world today and their findings, contextualizing the knowledge of people who lived two thousand years ago. Examples of this view are the late Pope John Paul II and Archbishop of Canterbury, UK, Rowan Williams, among others, who claim that do not acceptance the Theory of Evolution is a moral affront to religious knowing [12]. Carneiro and Contins [14] agree with this analysis, indicating that the Catholic religion and various Protestant strands have advocated that the Genesis are simply a symbolic construction of the creation process and should be understood as such. However the same authors acknowledge that some Evangelicals segments are absolutely refractory to any negotiation with the biblical text, particularly regarding the Theory of Evolution. In this context, the new Brazilian religious framework lacks relevant research.

In this whole situation of conflict between evolutionists and creationists, a survey in the UK in 2009 entitled "Rescuing Darwin", which resulted in a report of the same name was made. The research 
sought to capture the vision of the British population about Darwinian biological evolution; the results revealed a high alignment with creationist thinking and reject the ideas of Darwin [15]. Despite the semantic problems that any question of that report may have on inducing the respondents' reaction, some questions of that survey were replicated in Brazil and other questions of local interest were added [5]. Part of the motivation of this research derives from the Colombo's hypothesis [16] suggesting that the results would be different in the Brazilian population due to its religious spectrum would agree more with creationist ideas and would be more resistant to evolutionary approaches, which was not sustained with recent results obtained by Silva and Mortimer [5].

In the present study, a survey in the central-west of the Minas Gerais (MG) State, Brazil and in its metropolitan region of Belo Horizonte was carried out by using a questionnaire containing the $10^{\text {th }}$ question of the questionnaire based on the "Rescuing Darwin" questionnaire. "Some people argue that the teaching of evolution can be beneficial for the scientific development of mankind, and eliminate it would be harmful". This question aims at analysing whether the Brazilian population - with varied education levels and high religiosity consider the teaching of biological evolution beneficial and if its elimination would bring any harm to science and, in the first instance, to students' biology learning.

\section{Methodology}

The research took place in Itaúna and Formiga municipalities (MG State), covering the region of central-west MG State and its metropolitan area of Belo Horizonte.

The data collection instrument was a questionnaire with eleven multiple-choice questions, of which the first four are literal translations of the English Colombo's [16] questionnaire plus seven questions formulated specifically for this research, as it is presented on Table 1.

Table 1. Questionnaire

\begin{tabular}{|l|l|}
\hline $\begin{array}{l}\text { 1. Intelligent design, the idea that evolution alone is not } \\
\text { enough to explain the complex structures of some } \\
\text { living things, so the intervention of a designer is needed } \\
\text { at key stages. }\end{array}$ & $\begin{array}{l}\text { a) I partially agree } \\
\text { c) I partially disagree } \\
\text { d) I totally disagree } \\
\text { e) I don't know }\end{array}$ \\
\hline $\begin{array}{l}\text { 2. The theistic evolutionism, the idea that evolution is } \\
\text { the means that God used for the creation of all living } \\
\text { things on earth. }\end{array}$ & $\begin{array}{l}\text { a) I totally agree } \\
\text { b) I partially agree } \\
\text { c) I partially disagree } \\
\text { d) I totally disagree } \\
\text { e) I don't know }\end{array}$ \\
\hline $\begin{array}{l}\text { 3. The atheistic evolution, the idea that evolution makes } \\
\text { belief in God unnecessary and absurd. }\end{array}$ & $\begin{array}{l}\text { a) I totally agree } \\
\text { b) I partially agree } \\
\text { c) I partially disagree } \\
\text { d) I totally disagree } \\
\text { e) I don't know }\end{array}$ \\
\hline $\begin{array}{l}\text { 4. Young Earth Creationism, the idea that God created } \\
\text { the world sometime in the last 10,000 years. }\end{array}$ & $\begin{array}{l}\text { a) I totally agree } \\
\text { b) I partially agree } \\
\text { c) I partially disagree } \\
\text { d) I totally disagree } \\
\text { e) I don't know }\end{array}$ \\
\hline $\begin{array}{l}\text { 5. The thought of Darwin, the idea that humans evolved } \\
\text { by a process of evolution which removes any need for } \\
\text { God. }\end{array}$ & $\begin{array}{l}\text { a) I totally agree } \\
\text { b) I partially agree } \\
\text { c) I partially disagree } \\
\text { d) I totally disagree } \\
\text { e) I don't know }\end{array}$ \\
\hline $\begin{array}{l}\text { 6. On the idea that science classes should only address } \\
\text { creationism, the idea that God created all living beings } \\
\text { and they have not changed since then. }\end{array}$ & $\begin{array}{l}\text { a) I totally agree } \\
\text { b) I partially agree } \\
\text { c) I partially disagree } \\
\text { d) I totally disagree } \\
\text { e) I don't know }\end{array}$ \\
\hline $\begin{array}{l}\text { a) I totally agree } \\
\text { b) I partially agree } \\
\text { c) I partially disagree } \\
\text { d) I totally disagree } \\
\text { e) I don't know }\end{array}$ \\
\hline
\end{tabular}




\begin{tabular}{|l|l|}
\hline $\begin{array}{l}\text { 8. About a suggestion that science classes should give } \\
\text { the same value and use the same time to teach } \\
\text { creationism and the theory of evolution. }\end{array}$ & $\begin{array}{l}\text { a) I totally agree } \\
\text { b) I partially agree } \\
\text { c) I partially disagree } \\
\text { d) I totally disagree } \\
\text { e) I don't know }\end{array}$ \\
\hline $\begin{array}{l}\text { 9. Science and religion can have a peaceful coexistence, } \\
\text { even in an environment where ideas are so contrary as } \\
\text { biological evolution and creationism. }\end{array}$ & $\begin{array}{l}\text { a) I totally agree } \\
\text { b) I partially agree } \\
\text { c) I partially disagree } \\
\text { d) I totally disagree } \\
\text { e) I don't know }\end{array}$ \\
\hline $\begin{array}{l}\text { 10. Some people argue that the teaching of evolution } \\
\text { can be beneficial for the scientific development of } \\
\text { mankind, and eliminate it would be harmful I partially agree }\end{array}$ & $\begin{array}{l}\text { a) I totally agree } \\
\text { b) I partially disagree } \\
\text { c) I I totally disagree } \\
\text { e) I don't know }\end{array}$ \\
\hline $\begin{array}{l}\text { 11. It is impossible to believe in biological evolution } \\
\text { and at the same time believe in God. }\end{array}$ & $\begin{array}{l}\text { a) I totally agree } \\
\text { b) I partially agree } \\
\text { c) I partially disagree } \\
\text { d) I totally disagree } \\
\text { e) I don't know }\end{array}$ \\
\hline $\begin{array}{l}\text { 12. What is your opinion about the teaching of } \\
\text { evolution and creationism in schools? How would you } \\
\text { prefer that your child be educated regarding this issue? }\end{array}$ & $\begin{array}{l}\text { (Open question) } \\
\text { (O) }\end{array}$ \\
\hline
\end{tabular}

It consisting of a series of statements contained questions on the Likert scale format, in which the respondent should express their degree of agreement or disagreement each statement. It was validated by applying the Cronbach alpha test, obtaining the value of 0.617 .

The instrument was completed by 390 respondents; the majority $(62.6 \%)$ were female.

The average age of respondents was 30.7 years. No specific criteria for questionnaire application were predetermined.

\section{Results and discussion}

The questionnaire data analysis showed that, within the sample studied, there is an outstanding recognition of the importance of Darwinian theory to scientific progress, with $89 \%$ of respondents considering that the proposed statement is definitely true $(66 \%)$ or probably true $(23 \%)$ (Figure 1$)$.

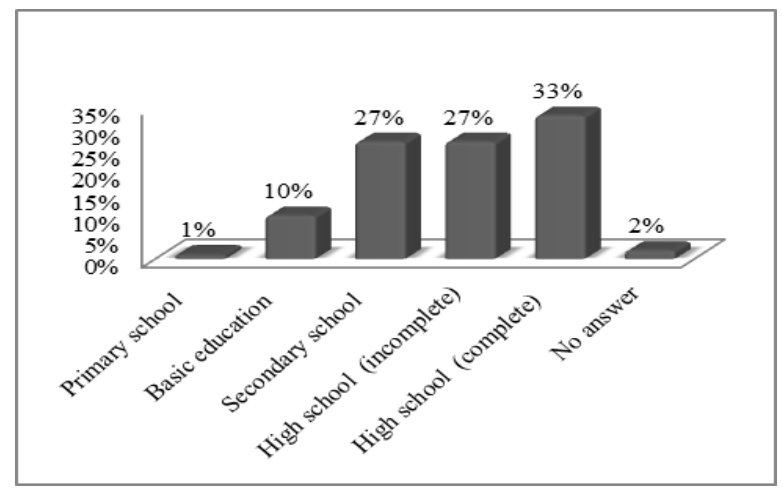

Figure 1. Respondents' answers to the question whether the teaching of evolution can be beneficial for the scientific development of mankind and eliminate it would be harmful.

These results seem to disagree with previous ones found by Silva et al. [5] regarding the rejection of evolutionary theory or the failure to consider a creator in the emergence of species, using the same questionnaire applied to the same public but when other question was analysed. This type of denial was found in Brazil, even in unusual environments, such as students of Biological Sciences courses, as shown by Silva et al. [17]. This contradiction may be due to the fact that even being highly religious, the biology 
teachers recognize the importance of Darwinian Theory to the teaching of biology and science as a whole, as suggested by Bizzo et al. [8] in an extensive survey of Brazilian students. According to Ian Barbour [18] these contradictions can be resorted through the relations between science and religion that can be categorized in four main groups: conflict, independence, dialogue and integration.

It can be suggested that the category of independence gives a possible answer to the contradiction that seems to have arisen when creationists recognize the value of teaching evolution. For these respondents, even preserving their dogmatic worldview, it is possible to recognize and live with knowledge that could bump into their faith and recognize their importance, as perceived by Bizzo et al. [8]. To go further in the analysis of the results on this issue, two variables in the survey were analysed: respondents' education and religiosity.
Figure 2 shows that the increase in education has a positive impact on recognition of the importance of Darwinian Theory. Respondents with less education showed a higher rate of the sentence rejection and had more difficulty to opine. With the increase in their academic career, the proportion of the sentence acceptance tended to increase, although the statistical analysis showed no significant differences ( $p>0.05$; Table 2). Therefore, one cannot say that the level of education affects directly the sentence acceptance or rejection. It must be emphasised that the samples for each category were not predetermined, i.e. the sampling procedure, on purpose, did not take into account the level of education or religion as criteria for inclusion. Nonetheless, these results are in agreement with those found by Silva e Mortimer (2014), with respect to increasing education contributes to acceptance of evolutionary ideas.

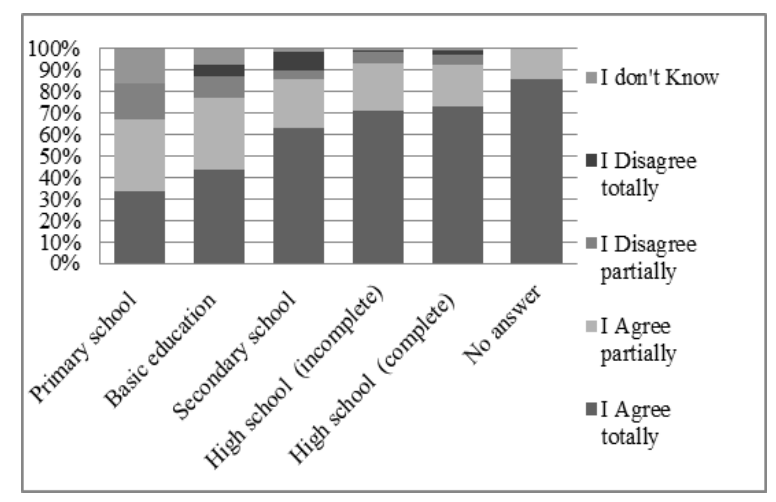

Figure 2. Respondents' answers to the question whether the teaching of evolution can be beneficial for the scientific development of mankind and eliminate it would be harmful, by education level.

A significant increase in the statement acceptance was found at the education level of high school. It becomes clear the influence of studying biological evolution (at High School) on students' ideas about it, who recognize better its relevance as a priority in the Brazilian secondary school curriculum proposal (http://portal.mec.gov.br/seb/arquivos/pdf/ciencian.p df). Similar results have been found by Silva et al [17] who have found, during the course of Biological Sciences, a growing acceptance of the Theory of Evolution, with the existence of a common ancestry, including the one of humans. Thus, according to these authors, there would be accommodation of scientific knowledge regarding the dogmatic view of most students, even the most religious ones. These data corroborate those found by Pagan [19] where students often live with both visions of the world, in a conciliatory reasoning, or simply refrain from thinking about it and about the conflict that it can generate.

This reconciliation falls within the Barbour's categories of dialogue and integration, as referred by Coutinho [18], when respondents are able to accommodate the two fields, religion and science.

These results support Berkman and Plutzer's [6] claim about the increase of the teaching of biological evolution in the curriculum, especially in secondary school, and the need for improving teachers' competencies on this subject, so that they can work better with their students in the process of teaching and learning. Rutledge and Mitchel [7] further claim that it is necessary to analyse how these teachers have learned the theme of Evolution in their own training, whether there had been enough information so that they can now make an appropriate approach in their classroom. 
Table 2. Chi-square test in relation to education, with a significance level of 5\% and degree of freedom 20

\begin{tabular}{|l|c|c|c|c|c|}
\hline \multicolumn{1}{|c|}{ Sample } & $\begin{array}{c}\text { I agree } \\
\text { totally }\end{array}$ & $\begin{array}{c}\text { I agee } \\
\text { partially }\end{array}$ & $\begin{array}{c}\text { I dis agee } \\
\text { partially }\end{array}$ & $\begin{array}{c}\text { I disagree } \\
\text { totally }\end{array}$ & $\begin{array}{c}\text { I don't } \\
\text { Know }\end{array}$ \\
\hline $\begin{array}{l}\text { Primary } \\
\text { school }\end{array}$ & 2 & 2 & 1 & 0 & 1 \\
\hline$\chi^{2}$ partial & 0.99 & 0.31 & 1.56 & 0.23 & 6.25 \\
\hline $\begin{array}{l}\text { Basic } \\
\text { Education }\end{array}$ & 17 & 13 & 4 & 2 & 3 \\
\hline $\begin{array}{l}\chi_{\text {partial }}^{2} \\
\text { Secondary }\end{array}$ & 3.06 & 2.00 & 2.00 & 0.17 & 6.05 \\
\hline $\begin{array}{l}\text { School } \\
\chi^{2} \text { partial }\end{array}$ & 66 & 24 & 4 & 9 & 2 \\
\hline $\begin{array}{l}\text { High School } \\
\text { (incomplete) }\end{array}$ & 74 & 23 & 5 & 1 & 1 \\
\hline$\chi^{2}$ partial & 0.35 & 0.01 & 0.02 & 2.25 & 0.60 \\
\hline $\begin{array}{l}\text { High School } \\
\text { (complete) }\end{array}$ & 94 & 25 & 6 & 3 & 1 \\
\hline$\chi_{\text {partial }}^{2}$ & 0.81 & 0.58 & 0.06 & 0.78 & 1.02 \\
\hline No answer & 6 & 1 & 0 & 0 & 0 \\
\hline$\chi^{2}$ partial & 0.39 & 0.21 & 0.36 & 0.27 & 0.14 \\
\hline Total & 259 & 88 & 20 & 15 & 8 \\
\hline$\chi^{2}$ calculado & 37,14 & & & & \\
\hline & & & & & \\
\hline
\end{tabular}

The Colombo [16] analysis of the English report "Rescuing Darwin" claims that there would be greater acceptance of Darwinian Theory among Spiritualists, because the followers of this doctrine are less compliant to the scientific issues. In fact, the present study also shows that of the religious groups (i.e. excluding atheists and non-religious respondents), the Spiritualists were those who showed greater agreement with the statement $(70.0 \%$
"I agree totally" + 20.0\% "I agree partially") and no rejection was found (Figure 3).

In contrast, the greater rejection to the statement occurred among Evangelicals (8.7\% "I disagree totally" + 13.0\%"I disagree partially"), but even among these, there was a small proportion (30.4\% "I agree partially") recognising the value of evolutionary theory in the today's world (Figure 3).

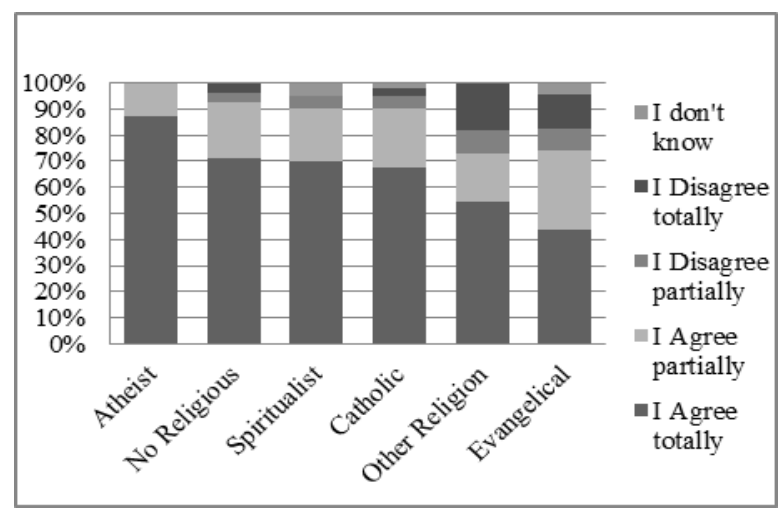

Figure 3. Respondents' answers to the question whether the teaching of evolution can be beneficial for the scientific development of mankind and eliminate it would be harmful, by religion.

The Catholics were in between Spiritualists and Evangelicals $(67.3 \%$ "I agree totally" + 22.7\% "I agree partially" and 5.0\% "I disagree totally" $+3.0 \%$ "I disagree partially"). These results agree with those found by Bizzo et al. [8].

According to the last Brazilian census (http://censo2010.ibge.gov.br/noticias-censo?view=noticia \&id=1\&idnoticia $=2170 \& \mathrm{t}=$ censo-2010-numero-catolicos- cai-aumenta-evangelicos-espiritas-sem-religiao), Evangelicals are the fastest growing religious group and those declaring having no religion are growing in numbers. Those who called themselves Atheists in this work agreed very much to Darwinian Theory and its importance to the modern world (100\% of "I agree totally"+ "I agree partially") (Figure 3). Thus, if the fastest growing population groups in Brazilian 
society are the Evangelicals (the most reluctant to Darwinian Theory) and the Atheists (the most aligned to Darwinian Theory) there will be a tendency for the polarization in the Brazilian religious field, which can lead, in the future, to problems in relation to teaching this subject.

The chi-square test showed that the religion variable had a high impact on agreement or disagreement with the statement of the role Darwinian Theory in modern science suggested in the questionnaire $(\mathrm{p}<0.05)$, confirming the initial hypothesis of this work.

Matching data of religion and education, it could be noticed that even among those belonging to the most aligned to creationism religions (Evangelicals), when having higher levels of education could recognise the value of Darwinian Theory to scientific development. So here is again the category of independence between science and religion proposed by Baubour [18], suggesting that even the most religious persons, when having contact with the Evolutionary Theory through regular education, can live with two apparently opposite views, being able to recognise the value of each one. This refutes the modern creationist movement claim that the Evolutionary Theory is incompatible with having a religion. Another recurring dogma is that evolution does not have scientific support [6], but data of this research showed that respondents with higher scientific educational level, even of creationist groups, recognise the relevance of Darwinian Theory and its importance to the modern world.

Therefore, in accordance to what has been found by Silva et al [17], it is difficult to accommodate scientific knowledge with religious beliefs, but it is possible and more achievable when one has a higher education level. In the view of Willemart and Marques [12] it is necessary to show in school scientific arguments and evidence of biological evolution, demonstrating its importance and its scientific bases, but also respecting the role of religion in society, delimiting clearly these two spaces of science and religion in school.

Finally, as Mayer \& El-Hani [2] claim, it must be recognized that the scientific knowledge learned in school can coexist with students' previous conceptions, including religious beliefs. According to these authors, the student is a subject that has built a world view, with their beliefs and values settled in family and social culture. Thus, in order to make students receptive to controversial issues, like biological evolution, one must work such issues without the prospect of eliminating their previous conceptions but, in contrary, recognizing its importance and allowing their adaptation to scientific knowledge. A simple example of this mutual respect of accommodation has been presented by MacDowell [20], arguing that for the perception of the sun moving around the earth, crossing the sky during the day, arguments can be given to make students understand that if the sun is seen as a regulator of life on our planet it is reasonable to say that it crosses the sky, but an astronomer will say that the earth is rotating around the sun. To find ways like this example allows the reconciliation of previous conceptions and beliefs concerning the human origin by God's creation, embodying the vision of the natural world, including humankind, as having arisen by natural evolution.

\section{Conclusion}

Most respondents can accommodate their religious dogmatic view built during their life with the scientific knowledge acquired at school and even when it seems to contradict their faith. This reveals some degree of independence between the two fields, religion and science. Results showed that for all Brazilian religious and non-religious groups there is room for the perception of the impact that Darwinian Evolutionary Theory has in modern science. This conclusion contradicts the view of some groups of radical atheists that claim the need to eliminate any trace of religiosity in school to allow accepting the idea of evolution and the humans' origin, i.e. assuming the idea of conflict between Science and Religion [20]. Finally, in contrast to the most radical creationists' claim, this study suggest that even in the view of those who profess a religion, the absence of teaching of biological evolution in school can be a harm for the regular education and for the scientific development.

\section{References}

[1] S. Ginnobili, "La utilidad de las flores: el movimiento del diseño inteligente y la biología contemporânea", Filosofia e História da Biologia, São Paulo, SP: ABFHiB, São Paulo, SP: FAPESP, Rio de Janeiro, RJ: Booklink, vol.8, n², 2013, p. 341-359. Retrieved December 21, 2013 from: http://www.abfhib.org/FHB/FHB-08-2/FHB-8-2-09Santiago-Ginnobili.pdf.

[2] D. Mayer, and C.N.O. El-Hani, "O que está em jogo no confronto entre criacionismo e evolução", Filosofia $e$ História da Biologia, ABFHiB, São Paulo, 2013, p. 211222.

[3] V. C. Sanz, "La evolución del creacionismo: del mito cosmológico e la pseudociência biológica", Filosofia $e$ História da Biologia, São Paulo, SP: ABFHiB, São Paulo, SP: FAPESP, Rio de Janeiro, RJ: Booklink, vol. 8, n²2, p.361-379, 2013. Retrieved December 21, 2013 from http://www.abfhib.org/FHB/FHB-08-2/FHB-8-2-10Vicente-Claramonte-Sanz.pdf.

[4] A. M. de A. Caldeira, E. S. N. N. de Araùjo, G. S. Carvalho, "Creationism and Evolution of Brazilian Teachers and Teachers-to-Be." Journal of Life Sciences. vol. $6, n^{\circ} 1,2012$ ou 2011. 
[5] H. M. Silva, E. F. Mortimer, Rescuing Darwin Brazil. In: Latin American Perspectives on Science and Religion. International Perspectives on Science, Culture and Society: 1. Pickering \& Chatto Publishers, 2014.

[6] M. Berkman, and E. Plutzer, "An Evolving Controversy." The Struggle to Teach Science Classes. American Educator. Summer 2012.

[7] M. L. Rutledge, M. A. Mitchell, "High School Biology Teachers' Knowledge Structure, Acceptance \& Teaching Evolution." The American Biology Teacher, vol. 64, nº 2002.

[8] N.M.V. Bizzo, A.M.S. GOUW, and H.M.R. Pereira, "Evolução e Religião: o que pensam os jovens estudantes brasileiros." Ciência Hoje, 2013, vol. 50, p. 26-31.

[9] M.V. Martins, "Quando uma sociologia da ciência se faz necessária: aspectos contemporâneos do embate entre criacionistas e evolucionistas." Filosofia e História da Biologia, ABFHiB, São Paulo, 2013, vol. 8, n² 2, p. 279299.

[10] R. Numbers. The creationists: from scientific creationism to intelligent design. Expanded Edition. Cambridge/London: Harvard Universi-ty Press, 2006.

[11] S. Shapin, "O Show de Darwin." Novos estudos CEBRAP, nº.87; São Paulo July 2010.

[12], R. H. Willemart, A. C. Marques, "Por que é tão difícil aceitar a evolução?” Ciência Hoje, no. 315, vol. 53, 2014, p. 24-27.

[13] M. Gleiser, "A Ciência e as Religiões." Jornal Folha de São Paulo, 22 de fevereiro de 2009, p. 3.

[14] S. S. Carneiro, M. Contins, "Religião e Espaço Público: religião nas escolas uma comparação entre Brasil e Estados Unidos." In: Brazilian Studies Association BRASA UVIII, 2006, Nashville, Tennessee, USA.

[15] N. Spencer, and D. Alexander, Rescuing Darwin: God and Evolution in Britain today. London: Theos, 2009.

[16] S. Colombo, "Darwin nas mãos de Deus." Folha de São Paulo, São Paulo, 2009, p. 4.

[17] H. M. Silva, E. S. N. N. Araujo, D. E. Gibram, G. S. Carvalho, Conceptual change about evolution and origins of life throughout an undergraduate course of Biological Sciences, In: Proceedings of INTCESS 14 - International Conference on Education and Social Science Proceedings, Istambul, Turkey, February, 2014, p. 1249-1258.

[18] F.A. Coutinho, and F.A.R. Silva, Ciência e Religião: uma guerra desnecessária, Ciência Hoje, 2013, vol. 51, nº 304, p.18-21.

[19] A. A. Pagan, Ser (humano) animal: evolucionismo e criacionismo nas concepções de alguns graduandos de Ciências Biológicas. Tese de doutorado. Faculdade de Educação da Universidade de São Paulo (USP), 2009.

[20] J. A. Macdowell, Evolução versus Criação. Veritas, vol. 56, nº 2, maio/agosto, 2011, p. 84-120. 